\title{
Environmental Quality and Health Status: Dynamic Ordinary Least Square Estimation for Developing Asian Countries
}

\author{
Saif Ullah ${ }^{1}$, Masood Sarwar Awan ${ }^{2}$ and Mahmood ul Hasan ${ }^{3}$
}

\begin{abstract}
The present study attempts to estimate the long-run relationship between health and environmental quality indicators along with other explanatory variables by using a balanced panel data for 20 developing Asian countries. Levin-Lin-Chu (LLC) and Im, Pesaran and Shin (IPS) unit root tests are employed for analyzing the panel unit root properties of data. Dynamic Ordinary Least Square (DOLS) is used to obtain the long-run estimates. The Carbon Dioxide (CO2) emission, Sulphur Dioxide (SO2) emission, and Particulate Matter (PM2.5) concentrations are used as environmental quality variables. Three models are estimated to assess the relationship between environmental quality and health. Life expectancy at birth is used as a proxy of health. The environmental quality indicators are negatively associated with health status showing an adverse effect on health. This means that air pollution is worsening human health in developing Asian countries. Per capita GDP is positively associated with health indicators in all models. Moreover, the urban population, access to improved sanitation facilities, and immunization are positively related to population health. These all variables are positively contributing to the improvement in public health. However, the effect of urban population is insignificant in the case of PM2.5. The effect of health expenditures on life expectancy is positive and statistically significant in the case of $\mathrm{CO} 2, \mathrm{SO} 2$ emissions, and PM2.5 concentrations. It shows a positive contribution of health expenditures towards improving life expectancy.
\end{abstract}

Keywords: Environment Quality, Air Pollution, Health, Per Capita GDP, DOLS

JEL Classification: I13, Q53, I1, O44, C12

\section{Introduction}

Sustainable development cannot be ensured without social wellbeing, good health, economic prosperity and environmental sustainability as recognized by the United Nation Environment Program (UNEP) and other international environmental agencies. The major impediments in the path of sustainable

\footnotetext{
${ }^{1}$ Lecturer, Department of Economics, University of Sarghoda.

${ }^{2}$ Professor, Department of Economics, University of Sarghoda.

${ }^{3}$ Assistant Professor, Department of Economics, University of Sarghoda.

Corresponding author's Email: saifullah.zafar@uos.edu.pk
} 
development are the emerging public health issues and environmental degradation, posing significant dangers to the survival of mankind. The interaction of public health and environmental issues has attracted researchers and other stakeholders in recent decades. The Earth Summit of 1992 at Rio de Janeiro documented the importance of human health and environmental relationships at the national and international levels for the first time. It urged researchers and policymakers to imagine how human health can be protected against environmental damages for achieving sustainable goals. This summit also identified the numerous social, economic and institutional factors behind environmental health hazards including rapid population growth, industrialization, urbanization, economic development, poverty, inequality, unemployment and political system. These factors have increased the pressure on natural and environmental resources, deteriorating the environment in the form of resource depletion, poor air quality and water pollution that in turn affect human health and quality of life.

The environmental issues have been overlooked for a long period and these issues can be classified into local, national and global based on their scale and nature. These issues including global warming, ozone depletion, climate change, pollution, biodiversity loss and ecosystem deterioration are endangering economic prosperity and social wellbeing. The environmental concerns appeared on the world agenda after the UNCHE conference of Stockholm in 1972. Later on, the famous notion of sustainable development was popularized as "development that meets the needs of the current generations without compromising the ability of the future generations to meet their own needs" (WCED, 1987, p. 45). In compliance with the Rio Declaration of 1992, a commission was created under the name UN Commission on Sustainable Development (CSD). This was later on converted into a high-level political agenda that was included in the schedule of the General Assembly meeting in 2013. Until now, various conferences have been organized committing to saving the ecosystem from environmental degradation. Similarly, a lot of reports have been published from the UN forum and other international scientific agencies under the UN patronage to recognize the significance of the health environment inter-relationship. The Millennium Ecosystem Assessment Report (2003) defined the basic human needs in five groups. And one group is related to the provision of a "livable environment". The present state of pollution contamination in the sphere of earth doesn't meet the required quality standards. This situation prevails in the third world countries where a major portion is unable to keep pollution under check. Weak governmental policies in these countries cannot also curb the ever-increasing pollution. 
There are several types of natural phenomena and human activities that lead to the degradation of the environment and depletion of natural resources. Massive urbanization, unchecked industrialization and the enormous population increase have been stretching the resources of earth beyond an irreversible limit. Moreover, irresponsible land uses, natural disasters, the addition of pollutants to land, atmosphere and aquatic bodies have further degraded the quality of life on the earth. Deforestation and excessive use of genetically modified organisms in the food and housing industry are taking the natural balance of the eco-systems to the verge of extinction. Noise and light pollutions are also adversely affecting the planet as well. Depleting Ozone by CFCs, imbalanced nitrogen concentration in the lithosphere, and global warming are only a few of the many challenges for the present generation. Human beings are exploiting the resources in a manner that would bring about an annihilation of their kind from the face of the earth in a matter of a few years. The UN International Strategy for Disaster Reduction explains that the environment is rapidly losing its capacity to meet ecological and social needs.

Air pollution is regarded as a crucial issue being faced by mankind on the earth for the past three decades. Public policies and debates have mainly focused on the industrial and vehicular emissions. However, they failed to take into account that these are not the only sources of air pollution especially in the under-developed regions of the world (Gurjar et al., 2016). The use of coal power generation plants, fossil fuel combustion, construction material, deforestation, fireworks, forest and field clearing through fire, and burning of waste are contributing grossly to polluting the atmosphere. The rise in population has also created several waste management problems in the world. The increased quantity of pollutants in the air would consequently increase the health risks besides the infant and child mortality rate in the world as the environmental quality is frequently declining due to the human activities on the earth (Brunekreef and Holgate, 2002). Unfortunately, the third world countries are severely underequipped and ignorant of the ways to properly handle their waste and are thus destabilizing the balance of the planet in general.

The World Health Organization has recognized particulate matter, O3, CO, sulfur oxides, nitrogen oxides, and lead $(\mathrm{Pb})$ as the major substance harming the atmospheric environment (Bayram et al., 2006). These air pollutants in particular are endangering the human, animal and plant life on the earth (Kampa and Castanas, 2008). More than 7 million people are dying annually by breathing contaminated air. 2.2 million out of the 7 million premature deaths around the world have been documented in Asia (WHO, 2016). There are many other long term (chronic) and (acute) short-term diseases including respiratory infections, skin allergy, throat 
infections, lung cancer and eye damage which are caused by air pollutants. These diseases have deleterious effects depending on the vulnerability, exposure, and sensitivity to these pollutants. Children and the elderly are more vulnerable to these air pollutants (Bayram et al., 2006). It is observed by many scholars that the reduction in air pollutants would lessen the global burden of disease and death. It would also improve the quality of life and save many species from extinction by balancing the eco-system (Öztürk, 2005).

The Intergovernmental Panel on Climate Change (IPCC) in its second and third report identified environmental effects on health, especially related to climate change and global warming. The UN's first human development report declared public health as the foremost wealth of economies which is not possible without a healthy environment. Scholars have studied the association between environmental pollution and human health and affirmed that air pollutants can affect human beings both directly and indirectly by destroying their quality of life. According to studies by WHO, 88 percent of the premature deaths in developing countries can be attributed to air pollution. The situation in the Asia Pacific region is exceptionally critical as the people are more exposed to black carbon due to the use of low-quality fossil fuels in vehicles and other transportation sources.

The State of Global Air report (2019) has listed five countries that have the highest rates of mortality resulting from air pollution. They include China, India, Pakistan, Indonesia, and Bangladesh. As many as 147 million lives were lost in 2017 due to pollution in these countries. Furthermore, about half of the global population is experiencing the deleterious effects of household air pollution. The report states that the life expectancy of the newborn is reduced by more than 30 months in South Asia while 20 months on an average at the global level. Air pollution causes more than 4 million deaths each year globally, whereas 1.5 million or $37 \%$ out of this death toll takes place in South and Southeast Asia. The Asian region is most affected by air pollution and environmental degradation. Thus, it is a dire need of the time to explore the full range of consequences of environmental degradation on human health.

The developing Asian region is badly affected by environmental pollution as mentioned above. Therefore, the current work mainly intends to explore the consequences of environmental quality on health status for developing Asian region. As reported by different international organizations, the majority of the people of these countries face hazardous health conditions due to the poor environmental quality. The current work differs from earlier studies on the relationship between environmental quality and health on the choice of 
environmental quality indicators used for underdeveloped Asian region. The study also contributes to existing literature by applying recent econometric methodology. The rest of the paper is structured as follows. Section two contains the review of earlier studies on the relationship between health status and different pollution indicators. Data description and methodology are explained in section three while section four comprises results, discussion, and suggestions. Concluding remarks are provided in the last section.

\section{Literature Review}

There is a large body of considerable flourishing literature that explores the association between the environmental quality proxies and human health at the country and cross-country levels. Country-specific studies have analyzed the impact of the daily and weekly variations in air quality on human health, also known as epidemiological studies. The focus of the cross-country studies rests on the impact of the local pollutants on health at different locations by considering other socio-economic factors. Some studies are based on panel analysis while others are natural experimental. Panel studies are concerned with the analysis of the relationship between different indicators of pollution and certain health variables for a group of countries. A few studies are reviewed in this section. Donohoe (2003) found the causes and consequences of environmental degradation and social injustice. This analysis found that environmental degradation was caused by global warming, overconsumption, overpopulation, unequal distribution of income, debt crises, war, deforestation, pollution, indefensible agriculture, and the rise of corruption. Based on literature and reports it was found that environmental degradation was the main cause of poverty, famine, overcrowding, extreme weather conditions, chronic medical illnesses, species loss, and an unstable global situation. Narayan and Narayan (2008) employed a panel data to examine the relationship between environmental quality and health status for selected OECD countries. The study applied Pedroni (1999) test for analyzing the existence of the co-integration relationship. Panel OLS and DOLS techniques were applied to estimate the long and short-run elasticities. The study used NO2, $\mathrm{SO} 2$ and carbon monoxide emission to capture pollution effect on health expenditures which were used as an indicator of health. Results found that NO2, SO2 and carbon monoxide emission inversely affected the health status. Furthermore, the findings suggested that the health policy should be formulated by taking into account environmental quality situation for the welfare of the community.

Kampa and Castanas (2008) explained the effect of air pollution on human health. They described that air pollutants like nitrogen oxide, carbon monoxide, 
sulfur dioxide emission, ozone, and heavy metal negatively impacted the health condition of a society. Heart attacks, respiratory diseases, lung cancer and respiratory infections in children are caused by pollution. It was concluded that pollution reduced life expectancy and enhanced mortality rate. Balakrishnan et al. (2019) explored the effect of air pollution using PM2.5 as a pollution indicator on life expectancy, mortality rate and burden of diseases for the states of India. Data on pollution measures were gathered from $\mathrm{GBD}^{4}, 2017$. The findings affirmed Delhi, Uttar Pradesh, Bihar, Jharkhand, Odisha and Haryana were more affected by PM2.5 concentrations because of their high death rates. The states having high income were found to have more burden of disease due to PM2.5 concentrations. Those having low income were more affected by household pollution. Life expectancy reduced by 0.7 to 0.9 years due to increased pollution levels. Moreover, India was facing high PM2.5 concentrations levels. Mutizwa and Makochekanwa (2010) analyzed the relationship between health status and environmental quality by using the infant mortality rate as a proxy of health status for 12 South African countries. The study used three environmental quality variables including carbon dioxide emission, improved sanitation facilities and access to improved water by employing panel data from 2000 to 2008 . FE and RE models were employed for the empirical analysis and findings concluded a positive association between carbon dioxide emission and health variables. Moreover, the results found that other environmental indicators were negatively linked with infant mortality rate implying that improved sanitation facilities and access to improved water have a positive effect on the health status. The results of the fixed effects model indicated that access to improved sanitary facilities and water had a negative and significant impact on infant mortality. The outcomes of the random effects model showed that carbon emissions had no significant impact on infant mortality, while access to improved water and improved sanitary facility had a positive and significant influence on health status.

Drabo (2010) investigated the relationship between environmental quality, health and economic growth in both rich and poor countries. A panel data of 117 developing and developed countries was used. It was collected from the WDI and David Stern database. Economic growth was measured by GDP per capita while environmental quality was proxied by carbon dioxide emission, biological oxygen demand and sulfur dioxide emission. The 2SLS and Two-step GMM methods were adopted to compute the results empirically. The empirical investigation found that economic growth was negatively affected by environmental degradation. Environmental degradation reduced the ability of developing countries to reach

${ }^{4}$ Global Burden of Diseases, Injuries, and Risk Factors Study. 
developed nations. It was concluded that health plays an important role in linking economic growth and the environment. Ali and Audi (2016) explored the impact of globalization and environmental deterioration on life expectancy along with the role of income inequality in the case of Pakistan. The study used annual data from 1980 to 2015 collected from the WDI database, Pakistan Bureau of Statistics, and Freedom House's various publications. The study used the ARDL co-integration approach for estimating parameters. The findings revealed that life expectancy was negatively affected by income inequality and environmental deterioration for Pakistan.

Ghorani et al. (2016) demonstrated the impact of air pollution on human health in the case of Iran. There were a lot of sources of pollution, but industry and vehicles contributed a major part. Major air pollutants were ozone, carbon monoxide, nitrogen oxide, sulfur oxide and particle matters. It had a worse impact on human health in the form of various diseases like skin disease, eye irritation, neuro-psychiatric complications, fetal growth, autism, low birth weight, respiratory disease and cancer. It was suggested that pollution can be reduced by adopting measures such as planting trees, increasing the price of fuel, replacing the old cars with modern ones, increasing road tax, improving public transport, imposing a penalty for polluting industry, monitoring air quality and running an awareness media campaign. Chopra (2016) elaborated on the causes and consequences of environmental degradation in the case of India. It was derived based on different reports that environmental degradation occurs because of higher population growth, higher poverty rate and large-scale urbanization. The environment was also affected by the pattern and level of development. Air pollution because of fuel adulteration, wood fuel, biomass burning, and vehicular emissions also affected health inversely. There was no environmental law that also negatively affected health outcomes. It was also documented that a major cause of loss of biodiversity was global warming, pollution, deforestation, and overpopulation.

Fotourehchi (2016) analyzed the health and pollution nexus by adopting the Recursive Simultaneous Equations model for developing countries. The study utilized unbalanced panel data of 60 developing countries gathered from WDI, 2016 and World Health Organization. It used different indicators of pollution including $\mathrm{CO} 2$ emission and PM10, and health status was proxied by life expectancy and infant mortality. The pollution equation results showed that population density, globalization, urbanization, and per capita GDP were positively linked with pollution variables while education level was inversely related to $\mathrm{CO} 2$ emission and PM10. The health equation findings revealed that pollution had negative consequences for health. Gwangndi et al. (2016) analyzed the impact of 
environmental degradation on the health condition of human beings under the patronage of international health laws in Nigeria. The study also explored the causes and consequences of environmental degradation. Based on the doctrinal method of research, it was found that environmental degradation had adverse effects on the health conditions of the public in violation of health laws. It was suggested that the country should work for protecting the health of people under the umbrella of international laws developed in the recent decades. It was also concluded that the government and international organizations must concertedly work for improving the health and environmental conditions.

Huang et al. (2018) explored the negative consequences of air pollution wave on the mortality rate in Tianjin, China for the period 2006-2011. Data were taken from the Ministry of Environmental Protection, China. The study used different pollution variables such as PM10, NO2 and SO2 and examined their impact on mortality rate. A study conducted a daily and durational analysis and found that death rates were positively correlated with air pollution indicators and had severely (negatively) impacted human health. Furthermore, the findings recommended that measures should be taken to reduce environment-related health risks. Ahmad et al. (2018) investigated the effect of environmental quality and socio-economic variables on human health by adopting the ARDL approach. The study employed time series data ranging from 1960-2014 for China. CO2 emission, per capita income, and urban population were used as a proxy of environmental quality, social and economic factors. The findings showed that $\mathrm{CO} 2$ emission exerted a negative influence on health status in China in the long run. The same relationship was found in the short run. The study concluded that the government should focus on the policies aiming at the reduction of $\mathrm{CO} 2$ emission.

Apte et al. (2018) studied the correlation between health and exposure to particulate matter PM2.5 for 185 countries. The life-table analysis techniques that consists of five major reasons for death were used for analysis and data was gathered from the Global Burden of Diseases 2016 dataset. The analysis found a significant relationship between exposure to PM2.5 and decrement in life expectancy especially for polluted countries of Asia, Africa, and the Middle East. Findings confirmed the one-year loss of life expectancy globally and 1.2 to 1.8 years reduction in life expectancy in the low-income countries due to exposure to PM2.5. Furthermore, the results reported higher life expectancy in the high-income countries and lower for the low-income countries. Abdolahnejad et al. (2019) examined the impact of air pollutants such as $\mathrm{SO} 2, \mathrm{NO} 2$ and $\mathrm{O} 3$ on health approximated by total mortality in Isfahan, Iran. The study used primary data collected from Isfahan's Department of Environment and Health Center. 
Descriptive analysis was carried out and the results demonstrated that there was a significant increase in deaths due to exposure to air pollutants. Moreover, the results found a significant increase in hospital admissions due to higher pollutants concentrations. The findings suggested the need for considerable attention by the government to reduce emissions of pollutants to protect human health.

Blázquez et al. (2019) conducted a study to analyze the impact of air pollution on health for 29 OECD countries, employing data whose duration was from 1995 to 2014. It was collected from different sources ${ }^{5}$. Health was proxied by health expenditures, and nitrogen oxides, sulfur oxides and carbon monoxide emission were used as pollution variables. Second generation panel stationary tests and panel DOLS were adopted to obtain the empirical estimates. The empirical estimates demonstrated that per capita income and pollution variables exerted a positive and negative impact on health expenditures, respectively. Nkalu and Edeme (2019) investigated the effect of environmental hazards on life expectancy using time series data of Nigeria from 1960 to 2017. Environmental hazards were proxied by $\mathrm{CO} 2$ emission and health status by life expectancy to examine the desired correlation. After analyzing the unit root properties by ADF and PP test and co-integration by the Johansen co-integration test, the study adopted a GARCH model to obtain empirical estimates. The finding showed that $\mathrm{CO} 2$ emission reduced life expectancy by 2 months while the income and population growth rate exerted a positive impact on life expectancy. The results suggested legal restrictions on $\mathrm{CO} 2$ emissions to control its negative effects on health.

\section{Data and Methodology}

\subsection{Model Specification}

The study aims to explore the association between health status and environmental quality indicators for developing countries of Asia. After the seminal work of Grossman (1972) regarding the health production function which includes environmental quality, several researchers (Barwick et al., 2017; Deschenes et al., 2017 and Narayan and Narayan, 2008) have identified various socio-economic determinants of health including age, income, income inequality, urbanization, population density, number of doctors and health expenditures. The following econometric relationship is proposed by considering (Drabo, 2011; Zaidi and Saidi, 2018 and Fotourehchi, 2016) and based on earlier empirical work.

$$
\text { Health }=\mathrm{f}(\text { EQ,GDPPC,UP,ISF,DPT,HE) }
$$

\footnotetext{
${ }^{5}$ OECD Health Statistics and OECD Environment Statistics.
} 
EQ denotes environmental quality. Carbon Dioxide (CO2) emission, Sulphur Dioxide (SO2) emission, and Particulate Matter (PM2.5) are environmental quality variables that measure the level of pollution in the air. This study focuses on the air pollution indicators because an individual breathes 13,00016,000 liters of air per day, so the impact of pollution on health is evident (Öztürk, 2005). There are many other reasons such as $\mathrm{CO} 2$ emission, which is a major source of air pollution, causing asthma and throat diseases while SO2 emission is helpful in the production of dangerous compounds such as sulfurous acid, sulfuric acid, and sulfate particles leading to several health issues which include respiratory ailments, eye irritation and lung diseases. PM2.5 denotes particulate matter less than size $2.5(\mu \mathrm{m})$ aerodynamic diameters which are a collection of small particles in the air that affect human health in the form of cardiac and lung diseases and bronchitis.

Particulate matters have been classified into different categories based on size such as PM0.1, PM2.5 and PM10 also known as ultrafine, fine and coarse particles. The study focuses on PM2.5 because these particles are more injurious to human health than others. These are invisible, light, and small in size and can remain suspended in the air for a longer period. Fine particles have been declared the 5th leading death factor due to serious health concerns by the World Health Organization. These particles originate from vehicular emissions, wood smoke, dust, dirt, industrial activities, and chemical reactions, etc. Particulate matters not only affect human health in the form of premature deaths, but they also damage plants and crops in the form of acid rain when they merge with moisture. The effect of particulate matters on human health differs depending upon size, intensity and level of exposure. These pollutants pollute the air, which in turn adversely affects human health, increasing the mortality rate. The effect of environmental quality variables is predicted to be negative on health.

Several studies have used infant and adult mortality rates and DisabilityAdjusted Life Year (DALY) per capita as a proxy of health status. The use of infant and adult mortality rates restricts the analysis to infant health and adult health that captures a very small fraction of the population while DALY is not used for the macroeconomic analysis. This study uses life expectancy (LE) at birth to represent health status because life expectancy captures infant as well adult health. Moreover, Drabo (2011) considers life expectancy a better and sufficient measure of health particularly for the developing countries because it captures overall public health.

GDPPC denotes per capita gross domestic product and is used to measure the level of income, which is likely to exert a positive effect on health as 
improvement in income provides better education and healthcare facilities to individuals. Urban population is represented by UP and is measured as the percentage of urban population utilized as a demographic variable. Population growth holds a key responsibility in maintaining environmental sustainability, but it results in environmental damage if it is more than the size of a country. Heavily populated areas are the result of higher population growth that deteriorates the environment through the overuse of natural resources generating air, water and land pollution and other environmental issues leading to several health risks. So it is expected to be negatively associated with health status. ISF and DPT ${ }^{6}$ denote improved sanitation facilities for the population expressed in the percentage and the percentage of children vaccinated against diphtheria, pertussis and tetanus in the age bracket of 12-23 months. Both the variables are likely to be positively correlated with health status. DPT has an important relation with life expectancy because childhood deaths are the main driver of variation in life expectancy over time and across locations. HE represents health expenditures taken as a percentage of GDP and an increase in expenditures on health is expected to improve the health of the population. The following econometric models are developed to examine the relationship between environmental quality and health.

\section{Model 1:}

$$
\begin{aligned}
L n L E_{i t}= & \phi_{0 i}+\phi_{1 i} L n C O 2_{i t}+\phi_{2 i} L n G D P P C_{i t}+\phi_{3 i} U P_{i t}+\phi_{4 i} I S F_{i t}+ \\
& \phi_{5 i} D P T_{i t}+\varphi_{6 i} H E_{i t}+\mu_{i t}
\end{aligned}
$$

Model 2:

$$
\begin{aligned}
L n L E_{i t}= & \delta_{0 i}+\delta_{1 i} L n S O 2_{i t}+\delta_{2 i} L n G D P P C_{i t}+\delta_{3 i} U P_{i t}+\delta_{4 i} I S F_{i t}+ \\
& \delta_{5 i} D P T_{i t}+\delta_{6 i} H E_{i t}+v_{i t}
\end{aligned}
$$

Model 3:

$$
\begin{aligned}
L n L E_{i t}= & \varphi_{0 i}+\varphi_{1 i} L n P M 2.5_{i t}+\varphi_{2 i} L n G D P P C_{i t}+\varphi_{3 i} U P_{i t}+\varphi_{4 i} I S F_{i t}+ \\
& \varphi_{5 i} D P T_{i t}+\varphi_{6 i} H E_{i t}+\varepsilon_{i t}
\end{aligned}
$$

This study seeks to assess the effect of environmental quality on health status for developing Asian economies by using panel data. The study uses a balanced panel data of 20 Asian countries ${ }^{7}$ covering the 1995 to 2016 period for model 1 and 1995 to 2010 for models 2 and 3, depending upon the availability of data. Data on SO2 emission measured in gigagram $(\mathrm{Gg})$ and PM2.5 emission

\footnotetext{
${ }^{6}$ Definition of all variables is provided in Appendix A.

${ }^{7}$ According to the World Bank Atlas method 2018-19 definition low income, lower middle income and upper middle income are declared as developing countries. The list of countries is provided in Appendix B.
} 
gigagram $(\mathrm{Gg})$ is collected from the $\mathrm{JRC}^{8}$ database. The data on life expectancy at birth, $\mathrm{CO} 2$ emission metric ton per capita, UP, ISF, DPT, HE and GDP ${ }^{9}$ per capita (constant 2010 US\$) have been retrieved from the WDI database, 2018.

\subsection{Levin-Lin-Chu Test (2002)}

LLC test applies to a balanced panel which assumes the autoregressive coefficient is uniform for the entire panel. LLC test is based on the following ADF regression:

$$
\Delta X_{i t}=\alpha_{i}+\rho_{i} X_{i, t-1}+\sum_{j=1}^{p_{i}} \hat{\pi}_{i j} \lambda_{i j} \Delta X_{i, t-j}-\gamma Y_{i t}+\varepsilon_{i t}
$$

The lag order $\mathrm{P}_{\mathrm{i}}$ is used for differenced term and it is allowed to differ across individuals. It is chosen to devise the residuals uncorrelated over time. $\mathrm{X}_{\text {it }}$ represents each variable under consideration in the model. $Y_{\text {it }}$ is the deterministic component and may be a fixed-effect or time trend. LLC is a three steps method. Augmented Dickey-Fuller (ADF) regression is estimated for each cross-section in the panel in the first step. The residuals are obtained from the two following auxiliary regressions in the second step:

$$
\begin{gathered}
\hat{\mathrm{e}}_{i t}=\Delta X_{i t}-\sum_{j=1}^{p_{i}} \hat{\pi}_{i j} \lambda_{i j} \Delta X_{i, t-j}-\gamma \widehat{\mathrm{Y}}_{i t} \\
\hat{\mathrm{v}}_{i, t-1}=X_{i t-1}-\sum_{j=1}^{p_{i}} \hat{\pi}_{i j} \lambda_{i j} X_{i, t-j}-\gamma \widehat{\mathrm{Y}}_{i t}
\end{gathered}
$$

The residuals are then weighted by the regression standard error to control for heterogeneity across cross sections, becoming $\tilde{\mathrm{e}}_{\mathrm{it}}$ and $\tilde{\mathrm{v}}_{\mathrm{i}, \mathrm{t}-\mathrm{l}}$ as;

$$
\begin{gathered}
\tilde{\mathrm{e}}_{i t}=\frac{\hat{\mathrm{e}}_{i t}}{\hat{\sigma} \varepsilon_{i}} \\
\tilde{\mathrm{v}}_{i, t-1}=\frac{\hat{\mathrm{v}}_{i, t-1}}{\hat{\sigma} \varepsilon_{i}}
\end{gathered}
$$

The standard error of each ADF is represented by $\hat{\sigma}$. Finally, a pooled t-statistic is computed by estimating the pooled OLS regression $\tilde{e}_{i t}=\rho \tilde{\mathrm{v}}_{\mathrm{i}, \mathrm{t}-1}+\tilde{\varepsilon}_{\mathrm{it}}$. Furthermore, the t-statistic is compared with table values for possible acceptance or rejection of the null hypothesis. The LLC test null hypothesis is that all cross-sections possess unit root against the alternative hypothesis that each series is stationary.

\footnotetext{
${ }^{8}$ European Commission, Joint Research Centre (JRC)/PBL Netherlands Environmental Assessment Agency database. ${ }^{9}$ Definition of all variables is provided in Appendix A.
} 


\subsection{Im, Pesaran and Shin (2003)}

Im et al. (2003) considers coefficients of auto-regressors to be different among countries. Im Pesaran-Shin unit root test also depends on the ADF principle and it depends on the following ADF regression as:

$$
\Delta Y_{i t}=\alpha_{i}+\rho_{i} Y_{i, t-1}+\sum_{j=1}^{p_{i}} \beta_{i} \Delta Y_{i, t-j}+e_{i t}
$$

$Y_{i, t}$ where $i=1,2,3 \ldots \ldots . N$, the series of panel countries over the period $\mathrm{t}=1,2, \ldots \ldots$. number of lags is $\rho_{\mathrm{i}}$ and disturbance term $\mathrm{e}_{\mathrm{it}}$ is auto correlated. The IPS test hypothesis is:

$$
\begin{gathered}
H_{0}: \rho_{i}=0 \text { for all } i \\
H_{1}: \rho_{i}<0 \text { for all } i=1,2 \ldots . N_{1} \\
H_{1}: \rho_{i}=0 \text { for all } i=N_{1+1}, N_{1+2}, \ldots . N
\end{gathered}
$$

The formula for computing test-statistics is

$$
t_{I P S}=\frac{\sqrt{N}[\bar{t}-E(\bar{t})]}{\sqrt{\operatorname{var}(\bar{t})}}
$$

$E(\bar{t})$ and $\operatorname{var}(\bar{t})$ are tabulated by IPS and created by simulations.

\subsection{Pedroni Co-integration test (1999)}

After applying the panel unit root test and confirmation of the integrated order of variables, the question arises whether co-integration exists between variables or not. In other words, a stochastic trend exists in variables in the long run or not. There are various residual-based and likelihood-based tests to examine the presence of a long-run relationship. The present study uses Pedroni's (2004) cointegration approach to do so. Pedroni test for co-integration is a residual-based test that permits considerable heterogeneity. Pedroni constitutes the null hypothesis of no co-integration. If the null hypothesis is rejected in the panel, the variables are said to be co-integrated. Moreover, it provides the appropriate critical values in complex regressions (Pedroni, 1999). Pedroni's (2004) cointegration tests are based on the following co-integrating regression.

$$
y_{i t}=\alpha_{i}+\delta_{i} t+\beta_{1 i} x_{1 i, t}+\beta_{2 i} x_{2 i, t}+\ldots \ldots+\beta_{M i} x_{M i, t}+e_{i t}
$$

Where

$$
\mathrm{i}=1,2, \ldots \ldots \mathrm{N} \text { (Number of individual in panel) }
$$


$\mathrm{t}=1,2, \ldots \ldots \mathrm{T}$ (Number of time periods)

$M=$ Number of regressors

Yit and Xit are variables integrated of order one

$\alpha_{i}=$ member specific intercept denoting fixed-effect or individual effect

$\delta_{i}=$ Parameters that represent time trend

$\beta_{1 i}=$ cointegration slope coefficients

$\mathrm{T}=$ number of observations over time,

$\mathrm{N}=$ number of individual or cross-section members in the panel

$\mathrm{M}=$ number of independent variables

Pedroni has proposed seven different co-integration statistics to obtain the between and within dimension effects in the panel. The first category includes four tests named; panel v-statistic, panel $\rho$-statistic, panel PP -statistic, and panel ADFstatistic which are based on pooling within the dimension. The second category includes three tests; group $\rho$-statistic, group PP-statistic, and group ADF-statistic which are based on pooling between the dimensions and are known as between dimension tests. After the evidence of the cointegration relationship, the subsequent procedure involves the estimation of long-run parameters by applying a suitable econometric technique. Because OLS yields inconsistent results in the presence of a cointegration relationship therefore the study adopts FMOLS and DOLS to obtain long-run estimates.

\subsection{Dynamic Ordinary Least Square (DOLS)}

The estimation of the long-run estimates in a co-integrated panel with the OLS will yield inconsistent and inefficient parameters therefore Kao and Chiang (1999) and Phillips and Moon (1999) recommended a panel dynamic OLS estimator (DOLS). Pedroni (2000) proposed a fully modified ordinary least square (FMOLS) estimation to estimate the long-run relationship. FMOLS is a nonparametric approach that accounts problem of endogeneity and serial correlation in the OLS estimator and it imposes additional restrictions on variables to have the same level of stationarity. DOLS is a panel analog of individual time series regressions developed by Saikkonen (1991) \& Stock and Watson (1993). The DOLS regression model is:

$$
y_{i t}=\phi_{i}+\delta_{t}+\dot{\beta}_{\imath} z_{i t}+\sum_{j=-p}^{p} d_{i j} \Delta z_{i, t+j}+\mu_{i t}
$$


Where,

$$
\begin{aligned}
& i=1,2,3, \ldots \ldots \ldots \ldots \ldots \ldots \ldots \ldots \ldots \ldots . . \mathrm{N}
\end{aligned}
$$

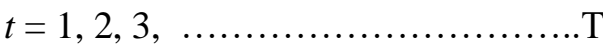

$$
\begin{aligned}
& \varphi_{\mathrm{i}}=\text { intercepts indicating individual fixed effects } \\
& \delta_{\mathrm{t}}=\text { time trend or effect }
\end{aligned}
$$

Zit is a vector of explanatory variables, $\beta_{\mathrm{i}}$ the estimated long-run impact, first-differenced regressors, leads and lags are shown by $\mathrm{p}$, while $\mathrm{d}_{\mathrm{ij}}$ is the coefficient of a lead or lag of the first differenced explanatory variables. $\mu_{i t}$ denotes the error term that should follow the $\mathrm{I}(0)$ process. The estimated coefficient of DOLS is given by:

$$
\widehat{\beta}_{D O L S}=\sum_{\mathrm{i}=1}^{\mathrm{N}}\left(\sum_{\mathrm{t}=1}^{\mathrm{T}} \mathrm{x}_{\mathrm{it}} \mathrm{x}_{\mathrm{it}}^{\prime}\right)^{-1}\left(\sum_{\mathrm{t}=1}^{\mathrm{T}} \mathrm{x}_{\mathrm{it}} \hat{\mathrm{x}}_{\mathrm{it}}\right)
$$

Where,

$$
\begin{gathered}
\qquad X_{i t}=\left[z_{i t}-\bar{z}_{i}, \Delta z_{i}, t-p, \ldots \ldots, \Delta z_{i}, t+p\right] \\
\mathrm{X}_{\mathrm{it}} \text { can be obtained through } 2(\mathrm{~K}+1) \mathrm{X} 1 \text { and } \hat{\mathrm{X}}_{\mathrm{it}} \text { can be obtained from } \mathrm{Z}_{\mathrm{it}}-\overline{\mathrm{Z}}_{\mathrm{i}} .
\end{gathered}
$$

DOLS is a parametric approach and uses leads and lags of differenced regressors to eliminate the issue of serial correlation and endogeneity. It also deals with small sample biases.

\section{Results and Discussions}

\subsection{Panel Unit root test results}

The prerequisite for cointegration analysis is that variables under consideration should be stationary for valid results. Therefore, it is essential to determine the unit root properties of variables. This study employs LLC and IPS tests that belong to the first-generation class of panel unit root tests. The results of IPS and LLC panel unit root tests are provided in the following tables. Panel unit root properties are analyzed separately for models 1,2 and 3 due to the difference in data span. The results of model 1 are provided in table 4.1 while model 2 and 3 results are presented in Table 4.2. 
Table 4.1: Panel Unit Root Test Results for Model 1

\begin{tabular}{cccccc}
\hline \multicolumn{5}{c}{ LLC } & \multicolumn{2}{c}{ IPS } \\
\hline Variables & At Level & $\mathbf{1}^{\text {st }}$ Difference & At Level & $\mathbf{1}^{\text {st }}$ Difference & Remarks \\
LnLE & $-5.650^{*}$ & -15.366 & $-1.3117^{*}$ & -15.912 & $\mathrm{I}(0)$ \\
LnCO2 & 2.418 & $-7.662^{*}$ & 4.959 & $-8.696^{*}$ & $\mathrm{I}(1)$ \\
LnGDPPC & 1.114 & $-4.712^{*}$ & 0.770 & $-5.338^{*}$ & $\mathrm{I}(1)$ \\
UP & $-1.997^{*}$ & -11.127 & $-2.621^{*}$ & -9.294 & $\mathrm{I}(0)$ \\
$\mathbf{I S F}$ & 3.418 & $-5.442^{*}$ & 7.220 & $-2.908^{*}$ & $\mathrm{I}(1)$ \\
DPT & $-0.941^{*}$ & -5.597 & $-1.587^{*}$ & -5.381 & $\mathrm{I}(0)$ \\
HE & 3.778 & $-1.885^{* *}$ & 4.808 & $-0.941^{* *}$ & $\mathrm{I}(1)$
\end{tabular}

Note: $* * *$ Shows $10 \%$, ** represents $5 \%$ and $*$ indicates $1 \%$ level of significance.

The IPS and LLC results suggest that some of the series namely LE, UP and DPT are stationary at level while GDPPC, CO2, ISF and HE are stationary at first difference showing mixed order of integration. This implies rejection of the null hypothesis of unit root at the $1 \%$ and $5 \%$ level of significance in both tests.

Table 4.2: Panel Unit Root Test Results for Model 2 and 3

\begin{tabular}{cccccc}
\hline \multicolumn{2}{c}{ LLC } & \multicolumn{2}{c}{ IPS } \\
\hline Variables & At Level & $\mathbf{1}^{\text {st }}$ Difference & At Level & $\mathbf{1}^{\text {st }}$ Difference & Remarks \\
LnLE & $-7.035^{*}$ & -21.253 & $-3.862^{*}$ & -21.556 & $\mathrm{I}(0)$ \\
LnSO2 & $-12.846^{*}$ & -19.602 & $-5.348^{*}$ & -8.104 & $\mathrm{I}(0)$ \\
LnPM2.5 & $-3.813^{*}$ & -6.073 & $-1.230^{*}$ & -3.841 & $\mathrm{I}(0)$ \\
LnGDPPC & 0.894 & $-5.428^{*}$ & 1.223 & $-2.711^{*}$ & $\mathrm{I}(1)$ \\
UP & $-4.437^{*}$ & -8.841 & $-3.894^{* *}$ & -13.532 & $\mathrm{I}(0)$ \\
ISF & 0.297 & $-0.807^{* *}$ & 2.274 & $-1.503^{* *}$ & $\mathrm{I}(1)$ \\
DPT & $-2.868^{*}$ & -6.282 & $-2.480^{*}$ & -7.104 & $\mathrm{I}(0)$ \\
HE & 4.932 & $-6.026^{*}$ & 7.697 & $-4.946^{*}$ & $\mathrm{I}(1)$ \\
\hline
\end{tabular}

Note: *** Shows $10 \%$, ** represents $5 \%$ and $*$ indicates $1 \%$ level of significance.

LLC and IPS results indicate that LE, SO2, PM2.5, UP and DPT reject the null hypothesis of non-stationary at level. GDPPC, ISF and HE reject the null hypothesis of non-stationary at first difference so there is a mixed order of integration among variables. These variables are stationary at the $1 \%$ and $5 \%$ level of significance in both tests. The next process is to examine the existence of the long-run relationship among LE, GDPPC, environmental degradation indicators, 
UP, ISF, DPT and HE. For this purpose, Pedroni (1999) and Kao (1999) tests are used and results are presented in Table 4.3 given below. The Akaike information criterion based on the smallest value is used for choosing the optimal lag length that is selected automatically.

Table 4.3: Panel Cointegration Results for Model 1-3

\begin{tabular}{|c|c|c|c|}
\hline Models & 1 & 2 & 3 \\
\hline Test Statistics & t-statistic & t-statistic & t-statistic \\
\hline Panel v-statistic & $\begin{array}{c}-7.255 \\
(1.0000)\end{array}$ & $\begin{array}{c}12.941 * \\
(0.0000)\end{array}$ & $\begin{array}{c}5.875^{*} \\
(0.0000)\end{array}$ \\
\hline Panel rho-statistic & $\begin{array}{c}2.926 \\
(0.9983)\end{array}$ & $\begin{array}{c}5.269 \\
(1.0000)\end{array}$ & $\begin{array}{c}4.134 \\
(1.0000)\end{array}$ \\
\hline Panel PP-statistic & $\begin{array}{l}-1.980^{*} \\
(0.0238)\end{array}$ & $\begin{array}{c}-0.593^{*} \\
(0.0264)\end{array}$ & $\begin{array}{c}-5.949 * \\
(0.0000)\end{array}$ \\
\hline Panel ADF-statistic & $\begin{array}{c}-2.602^{*} \\
(0.0046)\end{array}$ & $\begin{array}{c}-0.936^{*} \\
(0.0145)\end{array}$ & $\begin{array}{l}-5.434^{*} \\
(0.0000)\end{array}$ \\
\hline Group rho-statistic & $\begin{array}{c}5.023 \\
(1.0000)\end{array}$ & $\begin{array}{c}6.357 \\
(1.0000)\end{array}$ & $\begin{array}{c}5.900 \\
(1.0000)\end{array}$ \\
\hline Group PP- statistic & $\begin{array}{l}-2.353^{*} \\
(0.0093)\end{array}$ & $\begin{array}{c}-5.406^{*} \\
(0.0000)\end{array}$ & $\begin{array}{c}-3.829 * \\
(0.0001)\end{array}$ \\
\hline Group ADF-statistic & $\begin{array}{c}-4.016^{*} \\
(0.0000) \\
\end{array}$ & $\begin{array}{c}-5.177 * \\
(0.0000) \\
\end{array}$ & $\begin{array}{l}-3.993 * \\
(0.0000) \\
\end{array}$ \\
\hline \multicolumn{4}{|c|}{ Kao (1999) Residual Cointegration Test Results } \\
\hline Test & t-Statistic & t-Statistic & t-Statistic \\
\hline $\mathbf{A D F}$ & $\begin{array}{l}-6.732 * \\
(0.0000)\end{array}$ & $\begin{array}{l}-3.155^{*} \\
(0.0008)\end{array}$ & $\begin{array}{l}-2.867 * \\
(0.0021)\end{array}$ \\
\hline
\end{tabular}

The results of the Pedroni test illustrate that the majority of statistics do not reject the alternative hypothesis of co-integration against the null hypothesis of no co-integration for all models. Kao test results also suggest the presence of cointegration. Furthermore, after identifying the presence of a long-run relationship ${ }^{10}$ the study employs DOLS to estimate the long-run coefficients. The results of DOLS long-run estimates for all models are presented in the following table.

In model 1, environmental degradation is measured by air pollution using $\mathrm{CO} 2$ emission as a proxy that is negatively attached to life expectancy showing an adverse effect on health at the $1 \%$ significance level. This means that air pollution is worsening population health in developing countries. Fotourehchi (2016), Mutizwa and Makochekanwa (2010), and Zaidi and Saidi (2018) have similar findings for developing and sub-Saharan African countries. The impact of per capita income on health is positive and significant at the $1 \%$, indicating that

\footnotetext{
${ }^{10}$ Due to the short span of data only the long run parameters are estimated.
} 
improvement in income provides better healthcare opportunities to individuals. Nkalu and Edeme (2019) and Zaidi and Saidi (2018) have identical results about the effect of income on health status.

Table 4.4: DOLS Results

\begin{tabular}{cccc}
\hline $\begin{array}{c}\text { Variables } \\
\text { Independent } \\
\text { Variables }\end{array}$ & \multicolumn{3}{c}{ Dependent variables: log of Life Expectancy } \\
\hline LnCO2 & $\mathbf{1}$ & $\mathbf{2}$ & $\mathbf{2}$ \\
LnSO2 & $-0.059^{*}$ & & \\
& $(0.015932)$ & $-0.015^{* *}$ & \\
LNPM2.5 & & $(0.006111)$ & $-0.019^{* * *}$ \\
LNGDPPC & $0.033^{*}$ & $0.123^{*}$ & $(0.010024)$ \\
UP & $(0.007535)$ & $(0.021317)$ & $0.078^{*}$ \\
& $-0.001^{* *}$ & $-0.003^{*}$ & $(0.017516)$ \\
ISF & $(0.000894)$ & $(0.000594)$ & 0.001 \\
& & & $(0.000943)$ \\
DPT & $0.204^{*}$ & $0.002^{*}$ & $0.001^{* * *}$ \\
& $(0.012070)$ & $(0.000782)$ & $(0.000715)$ \\
HE & $0.001^{*}$ & 0.001 & 0.000 \\
& $(0.000395)$ & $(0.000463)$ & $(0.000310)$ \\
R-squared & $0.008^{*}$ & $0.016^{*}$ & $0.007^{*}$ \\
Adjusted R-squared & $(0.002033)$ & $(0.002966)$ & $(0.002281)$ \\
S.E. of regression & 0.929 & 0.925 & 0.970 \\
\hline Ne. & 0.924 & 0.917 & 0.962 \\
( $)$ & 0.0264 & 0.029 & 0.018 \\
\hline
\end{tabular}

Note: $(*)(* *)$ shows $1 \%$ and $5 \%$ statistical level of significance. Standard Errors are shown in parentheses.

Urban population is negatively associated with the health variable and is significant at the 5\% level of significance. This negative relationship is justified through many reasons in developing countries as half of the world population is living in urban areas posing a severe threat to environmental resources. It puts stress on natural resources and creates potential health hazards due to poor air and water quality that generates various diseases. This trend is increasing especially in Asia because people migrate to urban areas for better jobs, health and education facilities increasing pressure on the urban environment. The ISF and DPT coefficients also carry a positive sign and are statistically significant at the $1 \%$ significance level, showing favorable impacts on health.

The value of the DPT coefficient indicates that vaccination improves the health of the population because immunization is considered an effective tool to combat infectious and communicable diseases and it improves life expectancy by reducing mortality of children (Greenwood, 2014). Drabo (2011), Zaidi and Saidi 
(2018) and Ahmad et al. (2018) found similar findings about the impact of urban population, ISF and DPT on health. There is a positive link between health expenditures and life expectancy, but its value is very small. So there is a dire need to enhance budgetary allocations for healthcare services. Developing nations should invest in health sector for the betterment of health of their population.

The relationship between $\mathrm{SO} 2$ emission and health indicator is an inverse, showing deterioration in environmental quality ${ }^{11}$ by contamination of the air that affects human health negatively. Narayan and Narayan (2008), Drabo (2011) and Abdolahnejad et al. (2018) carried out a study and confirmed a negative correlation between SO2 and health variables for African countries and Iran. SO2 emission generates cardiovascular diseases, eye complications, lung cancer and respiratory issues by increasing mortality leading to a decrease in life expectancy in developing regions. SO2 mainly originates from the burning of fossil fuel and coal, industrial processes and gaseous consumption in developing regions. The governments of developing regions should devise a legal framework to limit SO2 emissions to protect their population from its negative impacts. The awareness programs about the negative consequences of pollution would be beneficial for reducing emissions that will reduce environmental health risks. The decrease in air pollution will also reduce economic costs in terms of decreased healthcare expenditures on public health and environmental health-related mitigation policies.

The per capita income and life expectancy are positively associated at the $1 \%$ significance level, implying a rise in income yields better healthcare services which leads to improvement in life expectancy. Blázquez et al. (2019) yielded the same findings for OECD countries. Growing urban population leads to environmental degradation, putting more pressure on environmental resources especially urban environment that results in air and water pollution contributing to more diseases. ISF is also positively attached to health status because it improves quality of life and reduces the burden of diseases. Drabo (2011) and Mutizwa and Makochekanwa (2010) have identical results. Health expenditures have a positive effect on health status and these findings are significant at the $1 \%$ significance level. Chaabouni and Saidi (2017) found a positive correlation between health expenditures and health status for developing countries. DPT also has a positive effect on health because improvement in immunization coverage reduces child mortality leading to higher life expectancy but insignificant statistically. These nations should concentrate on the provision of clean air and safe drinking water to their public to manage environment-related diseases.

\footnotetext{
${ }^{11}$ Deterioration in the environmental quality represents environmental degradation.
} 
The DOLS results for model 3 demonstrate that PM2.5 and life expectancy are negatively related at the $10 \%$ significance level showing that environmental quality is the main determinant of population health. The coefficient of PM2.5 indicates that the rise in air pollution decreases the life expectancy of the people. Similar results have been found by Apte et al. (2018) for 185 countries of Asia, Africa and the Middle East. To mitigate the negative consequences of particulate pollution, governments of developing countries should commit to spread awareness about the negative impacts of pollution on health. Per capita income exerts a positive and significant effect on life expectancy because an increase in income enables people to get better medical services that will improve life expectancy. Apte et al. (2018) and Chen et al. (2019) found identical findings. Access to sanitation facilities carries a positive sign and ISF coefficients are significant at the $10 \%$ significance level. The positive impact of access to sanitation facilities posits that increasing access to sanitation facilities contributes positively to improving health status that in turn raises life expectancy. The coefficients of the urban population show no impact on life expectancy in the case of PM2.5 because the value of UP is very small and insignificant. The effect of DPT is also insignificant. Health expenditures are positively associated with health status and significant at the $1 \%$ but having a very small coefficient. This implies that the governments of developing nations have a minor share in GDP for the health sector so they should allocate more funds for the healthcare services to mitigate the negative effects of environmental degradation.

\section{Conclusion and Policy Recommendations}

The study attempts to estimate the long-run relationship between health and air pollution indicators along with other explanatory variables by using a balanced panel data for 20 Asian developing countries. Levin-Lin-Chu (LLC) and Im, Pesaran and Shin (IPS) unit root tests are employed for analyzing the panel unit root properties of data. Findings are obtained by using the DOLS technique. Air pollution indicators including $\mathrm{CO} 2$ emission, SO2 emission and PM2.5 concentrations are negatively related with health status showing an adverse effect on health in all models. This means that air pollution is worsening population health in developing countries. Fotourehchi (2016), Mutizwa and Makochekanwa (2010), Zaidi and Saidi (2018), Narayan and Narayan (2008), Drabo (2011) Abdolahnejad et al. (2018) and Apte et al. (2018) have similar findings for developing and subSaharan African countries. It is acceptable because 97 percent of cities in developing countries fail to meet the World Health Organization air quality standards. The negative consequences of pollution are different for different people depending upon their period of exposure to pollution, age bracket, level of 
concentration and general health conditions. The rich and the poor people, children and the elderly, and the rural and urban population are victims of air pollution in these nations. But the poor are more vulnerable to pollution because they do not afford resources to mitigate the negative consequences of air pollution and a bad environment. The governments of these countries should improve air quality by implementing strict anti-pollution laws. This will help to control airborne diseases including heart diseases, stroke, lung cancer and respiratory complications, etc.

Air pollution can also be controlled by introducing cleaner sources of energy for transportation, heating, and cooking. Vehicular emission is the main contributor to air pollution in developing countries. But it can be reduced by using public transportation and tree plantation. Unprecedented economic growth of developing countries has resulted in rapid industrial and massive vehicular emissions posing several health risks. Indoor and outdoor air pollution originated from the combustion of biomass fuel, industrial and vehicular emissions has raised the risk of morbidity and mortality in individuals through many ways including exposure to $\mathrm{CO} 2, \mathrm{SO} 2$ emissions and particulate matters. The concentrations and retention of these gaseous and chemical particles in the atmosphere are a source of various respiratory, lung, and cardiovascular diseases. Excessive construction, solid and hospital waste, and massive fertilizer use are the main reasons for particulate pollution. Therefore, there exists a negative correlation between PM2.5 and proxy of health. There should be a proper waste management mechanism to control particulate pollution.

Initially, developing countries should set standards for air and adopt preventive measures to control pollution. Legislation and enforcement should be ensured to restrict industrial and vehicular emissions. Legal and technical measures to control industrial and vehicular emissions have been suggested by health scientists to mitigate pollution-related health risks. The governments should also make determined efforts to promote clean fuel technology for indoor cooking and heating to avert respiratory and cardiovascular diseases. Walking and cycling habits should be encouraged to control vehicular pollution. Wearing masks and traveling by closed vehicles are helpful actions that can reduce the risk of pollution borne non-communicable diseases.

The impact of per capita income on health is positive and significant indicating that the improvement in income provides better healthcare opportunities to the individuals in case of all pollution variables. Urban population is negatively associated with health variables and is significant statistically except for PM2.5 concentrations. Nkalu and Edeme (2019) and Zaidi and Saidi (2018) have shown 
identical results about the effect of income on the health status. This negative relationship is justified through many reasons in developing countries as half of the world population is living in the urban areas, severely threatening environmental resources and creating potential health hazards by putting stress on natural resources like air and water. This trend is increasing especially in developing Asian countries because people do migrate to urban areas for better jobs, health and education facilities enhancing pressure on the urban environment. The growing urban population in developing countries is grossly risking health by polluting air, water, and land through high consumption of natural resources. Land coverage is also a negative aspect of urbanization which is mostly occurring in developing countries. Local governments should play a leading role in conserving the urban environment and protecting the community from health hazards by adopting stringent urban planning, governance and city management policies. In this regard, public-private partnership is an effective tool that governments should opt for to improve sanitation, air quality, inadequate water supply, etc. Environmental health education can also play a vital role in controlling pollution. These nations need to devise regulation policies about the environment to enhance environmental quality. Sincere efforts regarding urban waste management are also needed to be made by the community and city governments to protect the environment.

The results conclude that there is a positive link between ISF, DPT and life expectancy for all models showing favorable impacts for improving health. Drabo (2011), Zaidi and Saidi (2018) and Ahmad et al. (2018) found similar findings about the impact of urban population, ISF and DPT. So the governments should expand vaccination coverage and ensure sanitation facilities for the welfare of the public. There is a positive correlation between health expenditures and life expectancy. It shows a positive contribution towards improving life expectancy. So, there is a dire need to enhance budgetary allocations for healthcare services. Developing nations should invest in health sector for protecting the health of their population. The reason behind the positive effect of sanitation is improvement in the quality of life through a reduction in the disease burden and improved nutrition. This ultimately enables people to participate in economic activities and avail job opportunities that will diminish economic loss. Similarly, immunization is considered an important tool for combating communicable and infectious diseases. Thus, an expansion of the immunization coverage will reduce the child mortality rate and enable children to live long. 


\section{References}

Abdolahnejad, A., Jafari, N., Mohammadi, A., Miri, M., \& Hajizadeh, Y. (2018). Mortality and morbidity due to exposure to ambient NO2, SO2, and $\mathrm{O} 3$ in Isfahan in 2013-2014. International Journal of Preventive Medicine, 9 (11).

Ahmad, M., Ur Rahman, Z., Hong, L., Khan, S., Khan, Z., \& Naeem Khan, M. (2018). Impact of environmental quality variables and socio-economic factors on human health: Empirical evidence from China. Pollution, 4(4), 571-579.

Ali, A., \& Audi, M. (2016). The impact of income inequality, environmental degradation and globalization on life expectancy in Pakistan: An empirical analysis. Available at: https://mpra.ub.uni-muenchen.de/71112/

Apte, J. S., Brauer, M., Cohen, A. J., Ezzati, M., \& Pope III, C. A. (2018). Ambient PM2. 5 reduces global and regional life expectancy. Environmental Science \& Technology Letters, 5(9), 546-551.

Assessment, M. E. (2003). Millennium ecosystem assessment, ecosystems and human well being. Island Press, Washington, DC, USA, 49-70.

Balakrishnan, K., Dey, S., Gupta, T., Dhaliwal, R., Brauer, M., Cohen, A. J., Aggarwal, A. N. (2019). The impact of air pollution on deaths, disease burden, and life expectancy across the states of India: The global burden of disease study 2017. The Lancet Planetary Health, 3(1), 26-39.

Barwick, M., Barac, R., Kimber, M., Akrong, L., Johnson, S., Cunningham, C., \& Godden, T. (2017). Evaluating evidence informed implementation: A multicase study of motivational interviewing in child and youth mental health. Manuscript submitted for publication.

Bayram, H., Dörtbudak, Z., Fişekçi, F. E., Kargın, M., \& Bülbül, B. (2006). Hava kirliliğinin insan sağlığına etkileri, dünyada, ülkemizde ve bölgemizde hava kirliliği sorunu" paneli ardından. Dicle Tip Dergisi, 33(2), 105-112.

Blázquez-Fernández, C., Cantarero-Prieto, D., \& Pascual-Sáez, M. (2019). On the nexus of air pollution and health expenditures: New empirical evidence. Gaceta Sanitaria, 33, 389-394.

Brunekreef, B., \& Holgate, S. T. (2002). Air pollution and health. The Lancet, 360(9341), 1233-1242. 
Chaabouni, S., \& Saidi, K. (2017). The dynamic links between carbon dioxide (CO2) emissions, health spending and GDP growth: A case study for 51 countries. Environmental Research, 158, 137-144.

Chen, C. C., Chen, P. S., \& Yang, C. Y. (2019). Relationship between fine particulate air pollution exposure and human adult life expectancy in Taiwan. Journal of Toxicology and Environmental Health, 82(14), 826-832.

Chopra, R. (2016). Environmental degradation in India: Causes and consequences. International Journal of Applied Environmental Sciences, 11(6), 15931601.

Deschenes, O., Greenstone, M., \& Shapiro, J. S. (2012). Defensive investments and the demand for air quality: Evidence from the $\mathrm{No}_{\mathrm{x}}$ budget program and ozone reductions (0898-2937). American Economic Review, 107(10), 295889.

Donohoe, M. (2003). Causes and health consequences of environmental degradation and social injustice. Social Science and Medicine, 56(3), 573587.

Drabo, A. (2010). Environment quality and economic convergence: Extending the environmental Kuznets curve hypothesis. Economics Bulletin, 30(2), 16171632.

Drabo, A. (2011). Impact of income inequality on health: Does environment quality matter? Environment and Planning , 43(1), 146-165.

Drabo, A. (2010). Interrelationship between health, environment quality and economic activity: What consequences for economic Convergence? University of Auvergne, Available at: https://halshs. archives-ouvertes. fr/halshs-00552995.

Fotourehchi, Z. (2016). Health effects of air pollution: An empirical analysis for developing countries. Atmospheric Pollution Research, 7(1), 201-206.

Ghorani-Azam, A., Riahi-Zanjani, B., \& Balali-Mood, M. (2016). Effects of air pollution on human health and practical measures for prevention in Iran. Journal of Research in Medical Sciences, 21(65).

Greenwood, B. (2014). The contribution of vaccination to global health: Past, present and future. Philosophical Transactions of the Royal Society B: Biological Sciences, 369(1645). 
Gurjar, B., Ravindra, K., \& Nagpure, A. S. (2016). Air pollution trends over Indian megacities and their local to global implications. Atmospheric Environment, $142,475-495$.

Gwangndi, M. I., Muhammad, Y. A., \& Tagi, S. M. (2016). The impact of environmental degradation on human health and its relevance to the right to health under international law. European Scientific Journal, 12(10), 485501 .

Huang, J., Pan, X., Guo, X., \& Li, G. (2018). Impacts of air pollution wave on years of life lost: A crucial way to communicate the health risks of air pollution to the public. Environment International, 113, 42-49.

IHME, \& Air, S. O. G.A. (2019). A special report on global exposure to air pollution and its disease burden. Institute for Health Metrics, Evaluation, and Health Effects Institute.

Im, K. S., Pesaran, M. H., \& Shin, Y. (2003). Testing for unit roots in heterogeneous panels. Journal of Econometrics, 115(1), 53-74.

Kampa, M., \& Castanas, E. (2008). Human health effects of air pollution. Environmental Pollution, 151(2), 362-367.

Kao, C. (1999). Spurious regression and residual based tests for cointegration in panel data. Journal of Econometrics, 90(1), 1-44.

Kao, C., \& Chiang, M. H. (1999). On the estimation and inference of a cointegrated regression in panel data. Available at: https://ssrn.com/abstract=1807931.

Levin, A., Lin, C. F., \& Chu, C. S. J. (2002). Unit root tests in panel data: Asymptotic and finite sample properties. Journal of Econometrics, 108(1), $1-24$.

Mutizwa, A., \& Makochekanwa, A. (2015). Impact of environmental quality on health status: A study of 12 Southern African development community (SADC) Countries between 2000 and 2008. Botswana Journal of Economics, 13(1), 87-111.

Narayan, P. K., \& Narayan, S. (2008). Does environmental quality influence health expenditures? Empirical evidence from a panel of selected OECD countries. Ecological Economics, 65(2), 367-374.

Nations, U. (2015). The millennium development goals report. New York, United Nations. 
Nkalu, C. N., \& Edeme, R. K. (2019). Environmental hazards and life expectancy in Africa: Evidence from GARCH model. SAGE Open, 9(1), 1-8.

Öztürk, M. (2005). Şehir içi bölgelerde hava kirliliğinin sağllk üzerine etkileri. Çevre ve Orman Bakanlığı, Ankara/Turkey, 251-268.

Pedroni, P. (1999). Critical values for cointegration tests in heterogeneous panels with multiple regressors. Oxford Bulletin of Economics and Statistics, 61(1), 653-670.

Pedroni, P. (2000). Fully modified OLS for heterogeneous cointegrated panels. Advances in Econometrics, 15, 93-130.

Pedroni, P. (2001). Purchasing power parity tests in cointegrated panels. Review of Economics and Statistics, 83(4), 727-731.

Pedroni, P. (2004). Panel cointegration: Asymptotic and finite sample properties of pooled time series tests with an application to the PPP hypothesis. Econometric Theory, 20(3), 597-625.

Phillips, P. C., \& Moon, H. R. (1999). Linear regression limit theory for nonstationary panel data. Econometrica, 67(5), 1057-1111.

Saikkonen, P. (1991). Asymptotically efficient estimation of cointegration regressions. Econometric Theory, 7(1), 1-21.

Stock, J. H., \& Watson, M. W. (1993). A simple estimator of cointegrating vectors in higher order integrated systems. Econometrica, 61(4), 783-820.

W.H.O. (2016). Ambient air pollution: A global assessment of exposure and burden of disease. Available at: http://apps.who.int/iris/bitstream/10665/ 250141/1/9789241511353-eng.pdf

World Bank. (1992). World Development Report 1992. New York, Oxford University Press.

World Commission on Environment and Development (1987). Our common future. Oxford, Oxford University Press.

Zaidi, S., \& Saidi, K. (2018). Environmental pollution, health expenditure and economic growth in the Sub-Saharan Africa countries: Panel ARDL approach. Sustainable Cities and Society, 41, 833-840. 
Environmental Quality and Health Status:

Dynamic Ordinary Least Square Estimation for Developing Asian Countries

\section{Appendix A}

Definition of Variables

\begin{tabular}{|c|c|c|c|c|c|}
\hline $\begin{array}{l}\text { Sr. } \\
\text { No }\end{array}$ & Variable & Symbol & Definition & Unit & Data Source \\
\hline 1 & $\begin{array}{l}\text { Carbon } \\
\text { Dioxide } \\
\text { Emission }\end{array}$ & $\mathrm{CO} 2$ & $\begin{array}{l}\text { Carbon dioxide emissions are those stemming } \\
\text { from the burning of fossil fuels and the } \\
\text { manufacture of cement. They } \\
\text { include carbon dioxide produced during } \\
\text { consumption of solid, liquid, and gas fuels. }\end{array}$ & $\begin{array}{l}\text { Metric } \\
\text { tons per } \\
\text { capita }\end{array}$ & $\begin{array}{l}\text { World Bank World } \\
\text { Development Indicator } \\
\text { (WDI 2018) }\end{array}$ \\
\hline 2 & $\begin{array}{l}\text { Sulfur } \\
\text { Dioxide } \\
\text { Emission }\end{array}$ & $\mathrm{SO} 2$ & $\begin{array}{l}\mathrm{SO}_{2} \text { is a colorless gas with a sharp odor. It is } \\
\text { produced from the burning of fossil fuels (coal } \\
\text { and oil) and the smelting of mineral ores that } \\
\text { contain sulfur. The main anthropogenic source } \\
\text { of } \mathrm{SO}_{2} \text { is the burning of sulfur-containing fossil } \\
\text { fuels for domestic heating, power generation } \\
\text { and motor vehicles. }\end{array}$ & $\begin{array}{l}\text { Gigagram } \\
(\mathrm{Gg})\end{array}$ & $\begin{array}{l}\text { European Commission, } \\
\text { Joint Research Centre } \\
\text { (JRC)/PBL Netherlands } \\
\text { Environmental } \\
\text { Assessment Agency } \\
\text { database }\end{array}$ \\
\hline 3 & $\begin{array}{l}\text { Particulate } \\
\text { Matters } 2.5\end{array}$ & PM2.5 & $\begin{array}{l}\text { PM2.5: fine inhalable solid and liquid } \\
\text { particles, with diameters that are generally } 2.5 \\
\text { micrometers and smaller. The major } \\
\text { components of PM are sulfate, nitrates, } \\
\text { ammonia, sodium chloride, black carbon, } \\
\text { mineral dust, and water. It consists of a complex } \\
\text { mixture of solid and liquid particles of organic } \\
\text { and inorganic substances suspended in the air. }\end{array}$ & $\begin{array}{l}\text { Gigagram } \\
(\mathrm{Gg})\end{array}$ & $\begin{array}{l}\text { European Commission, } \\
\text { Joint Research Centre } \\
\text { (JRC)/PBL Netherlands } \\
\text { Environmental } \\
\text { Assessment Agency } \\
\text { database }\end{array}$ \\
\hline 4 & $\begin{array}{l}\text { GDP Per } \\
\text { Capita }\end{array}$ & GDPPC & $\begin{array}{l}\text { The value of total production within the country } \\
\text { in a given year divided by total Population }\end{array}$ & $\begin{array}{l}\text { At } \\
\text { constant } \\
2010 \text { US } \\
\text { dollars }\end{array}$ & $\begin{array}{l}\text { World Bank World } \\
\text { Development Indicator } \\
\text { (WDI 2018) }\end{array}$ \\
\hline 5 & $\begin{array}{l}\text { Population } \\
\text { Density }\end{array}$ & PD & $\begin{array}{l}\text { Population density is the Number of individual } \\
\text { Per Square KM of land Area found as midyear } \\
\text { population divided by land area in square } \\
\text { kilometers. } \\
\text { (regarded as the population at July 1) }\end{array}$ & $\begin{array}{l}\text { Number of } \\
\text { individual } \\
\text { Per Square } \\
\text { KM of } \\
\text { land Area }\end{array}$ & $\begin{array}{l}\text { World Bank World } \\
\text { Development Indicator } \\
\text { (WDI 2018) }\end{array}$ \\
\hline 6 & $\begin{array}{l}\text { Urban } \\
\text { Population }\end{array}$ & UP & $\begin{array}{l}\text { Urban population refers to people living in } \\
\text { urban areas as defined by national statistical } \\
\text { offices. }\end{array}$ & $\begin{array}{l}\% \text { of Total } \\
\text { Population }\end{array}$ & $\begin{array}{l}\text { World Bank World } \\
\text { Development Indicator } \\
\text { (WDI 2018) }\end{array}$ \\
\hline 7 & Immunization & DPT & $\begin{array}{l}\text { DPT measures the percentage of children ages } \\
12-23 \text { months who received DPT vaccinations } \\
\text { before } 12 \text { months or at any time before the } \\
\text { survey. A child is considered adequately } \\
\text { immunized against diphtheria, pertussis (or } \\
\text { whooping cough), and tetanus (DPT) after } \\
\text { receiving three doses of vaccine. }\end{array}$ & $\begin{array}{l}\% \text { of } \\
\text { children } \\
\text { ages } 12-23 \\
\text { months }\end{array}$ & $\begin{array}{l}\text { World Bank World } \\
\text { Development Indicator } \\
\text { (WDI 2018) }\end{array}$ \\
\hline 8 & $\begin{array}{l}\text { Improved } \\
\text { Sanitation } \\
\text { Facilities }\end{array}$ & ISF & $\begin{array}{l}\text { Access to improved sanitation facilities refers to } \\
\text { the percentage of the population using improved } \\
\text { sanitation facilities. They include flush/pour } \\
\text { flush (to piped sewer system, septic tank, pit } \\
\text { latrine), ventilated improved pit (VIP) latrine, } \\
\text { pit latrine with slab, and composting toilet. }\end{array}$ & $\begin{array}{l}\% \text { of } \\
\text { Population } \\
\text { With } \\
\text { Access }\end{array}$ & $\begin{array}{l}\text { World Bank World } \\
\text { Development Indicator } \\
\text { (WDI 2018) }\end{array}$ \\
\hline 9 & $\begin{array}{l}\text { Health } \\
\text { Expenditures }\end{array}$ & $\mathrm{HE}$ & $\begin{array}{l}\text { Estimates of current health expenditures include } \\
\text { healthcare goods and services consumed during } \\
\text { each year. This indicator does not include } \\
\text { capital health expenditures such as buildings, } \\
\text { machinery, IT and stocks of vaccines for } \\
\text { emergencies or outbreaks. }\end{array}$ & $\%$ of GDP & $\begin{array}{l}\text { World Bank World } \\
\text { Development Indicator } \\
\text { (WDI 2018) }\end{array}$ \\
\hline
\end{tabular}




\section{Appendix B}

List of 20 Countries Included for the analysis of other objectives

\begin{tabular}{|c|c|c|}
\hline \multicolumn{3}{|c|}{ Region: Asia } \\
\hline Sr. No & Name of Country & Income Group \\
\hline 1. & Armenia & UPPER-MIDDLE-INCOME \\
\hline 2. & Bangladesh & LOWER-MIDDLE INCOME \\
\hline 3. & Bhutan & LOWER-MIDDLE INCOME \\
\hline 4. & Cambodia & LOWER-MIDDLE INCOME \\
\hline 5. & Turkey & UPPER-MIDDLE-INCOME \\
\hline 6. & Egypt & LOWER-MIDDLE INCOME \\
\hline 7. & India & LOWER-MIDDLE INCOME \\
\hline 8. & Indonesia & LOWER-MIDDLE INCOME \\
\hline 9. & Iran & UPPER-MIDDLE-INCOME \\
\hline 10. & Jordon & UPPER-MIDDLE-INCOME \\
\hline 11. & Lebanon & UPPER-MIDDLE-INCOME \\
\hline 12. & Malaysia & UPPER-MIDDLE-INCOME \\
\hline 13. & Maldives & UPPER-MIDDLE-INCOME \\
\hline 14. & Nepal & LOW-INCOME \\
\hline 15. & Pakistan & LOWER-MIDDLE INCOME \\
\hline 16. & Philippines & LOWER-MIDDLE INCOME \\
\hline 17. & Sri Lanka & UPPER-MIDDLE-INCOME \\
\hline 18. & Thailand & UPPER-MIDDLE-INCOME \\
\hline 19. & Vietnam & LOWER-MIDDLE INCOME \\
\hline 20. & Yemen & LOW-INCOME \\
\hline
\end{tabular}

https://blogs.worldbank.org/opendata/new-country-classifications-income-level-2018-2019.

http://www.economicsdiscussion.net/economic-development/developed-and-developing-countries-world-bankclassification-economics/30010.

\section{Appendix C}

\section{Statistical Software}

Eviews software is used for applying the LLC and IPS tests of unit root. Pedroni cointegration test and DOLS is also applied by using Eviews software. 